\title{
Spinocerebellar Ataxia Type 12 (SCA 12): Clinical Features and Pathogenetic Mechanisms
}

\author{
Ronald A. Merrill, Andrew M. Slupe and Stefan Strack \\ University of Iowa Carver College of Medicine \\ USA
}

\section{Introduction}

Spinocerebellar Ataxia 12 (SCA12) is a rare disease that was first identified in a family in the United States. Patients suffered from classical spinocerebellar ataxia symptoms with an age of disease onset ranging from 8-55 years. A trinucleotide (CAG) repeat expansion was confirmed in all the affected individuals. The CAG expansion mapped to the $5^{\prime}$ untranslated region (UTR) of the PPP2R2B gene. This gene encodes a regulatory subunit, $B \beta$, of the heterotrimeric protein phosphatase 2A (PP2A). The function of this particular PP2A complex is not well understood, and the underlying molecular mechanism of SCA12 remains unclear. Additional pedigrees have been identified throughout the world but SCA12 remains a rare disease. In this chapter we will discuss the clinical manifestation of the disease and the known functions of the PP2A regulator $\mathrm{B} \beta$.

\section{Molecular genetics and Incidence}

SCA12 is defined as an autosomal dominant cerebellar ataxia (ADCA) of otherwise unknown cause concurrent with a CAG repeat expansion within chromosome 5q31-33 upstream of the PPP2R2B gene (Holmes et. al., 1999). The PPP2R2B gene product, termed $\mathrm{B} \beta$, is a neuron specific regulatory subunit of the heterotrimeric PP2A (Strack et. al., 1998). PP2A has been shown to play an essential role in many cellular functions (Janssens \& Goris, 2001). The CAG repeat expansion associated with SCA12 was first identified through an unbiased repeat expansion detection study and found to occur within the noncoding region of the PPP2R2B gene (Holmes et. al., 1999). The nonpathalogical range of allele expansion is quite large (7-45 repeats) and is highly dependent on ethnic background (Fujigasaki et. al., 2001; Holmes et. al., 1999). The lower extreme of the range of pathological allele expansion has been established as 51 repeats. As is common to all ADCA disorders, inheritance of SCA12 follows an autosomal dominant pattern wherein a CAG repeat expansion of pathological length in just one allele is sufficient to induce the SCA12 disease state. Unlike other neurodegenerative diseases associated with a CAG repeat expansion, such as Huntingon disease, the number of CAG repeats associated with SCA12 does not correlate with the age of disease onset (Srivastava et. al., 2001). In addition, nondirectional vertical instability in the length of the expanded allele has been observed, however its clinical significance is unknown (Srivastava et. al., 2001). One individual has been identified with 
pathological repeat expansions in both alleles; however, due to the young age of this patient, it is unclear what effect homozygosity will have on the disease phenotype (Bahl et. al., 2005).

The world-wide incidence of SCA12 is quite low. Nonetheless, SCA12 has been identified across the globe in independent populations. The results of ADCA population screens that have examined the CAG repeat of the PPP2R2B gene are summarized below (Table 1), regardless of whether a SCA12 pathological CAG repeat expansion was identified. The well characterized SCA12 patient populations will hereafter be referred to as the American, Indian, Italian and Chinese cohorts when referencing the work by Holmes, et. al. (1999) and O'Hearn, et. al. (2001); Fujigaski, et. al. (2001), Srivastava, et. al. (2001) and Bahl, et. al. (2005); Brusco et al. (2002) and Brussino, et. al. (2010); and Jiang, et. al. (2005-1), Jiang, et. al. (2005-2) and Wang, J., et. al. (2011).

\begin{tabular}{|c|c|c|c|c|c|}
\hline Study & County & $\begin{array}{c}\text { Affected } \\
\text { families } \\
\text { (individuals) }\end{array}$ & $\begin{array}{c}\text { Pathalogical } \\
\text { (CAG) })_{n} \text { repeat } \\
\text { expansion (range) }\end{array}$ & $\begin{array}{l}\text { Healthy Population } \\
\text { (CAG) })_{n} \text { repeat } \\
\text { expansion (range) }\end{array}$ & $\begin{array}{l}\text { Age range in } \\
\text { years of disease } \\
\text { onset (mean) }\end{array}$ \\
\hline $\begin{array}{l}\text { (Holmes, 1999) \& } \\
\text { (O'Hearn, 2001) }\end{array}$ & United States & $1(10)$ & $66-78$ & $7-28$ & $8-55(34)$ \\
\hline $\begin{array}{l}\text { (Fujigasaki, } \\
\text { 2001) }\end{array}$ & Indian & $1(9)$ & $55-61$ & $9-45$ & $39-41(40)$ \\
\hline $\begin{array}{l}\text { (Srivastava, } \\
\text { 2001) }\end{array}$ & Indian & $5(6)$ & $55-69$ & $7-31$ & $26-50(37.2)$ \\
\hline (Bahl, 2005) & Indian & $20(81)$ & $51-69$ & $8-23$ & $26-56(40.2)$ \\
\hline (Brussino, 2010) & Italian & $2(3)$ & $57-58$ & NA & $45-60(52)$ \\
\hline (Jiang, $2005-1$ ) & Chinese & 1 (NA) & NA & NA & NA \\
\hline (Wang, J., 2011) & Chinese & $1(9)$ & $51-52$ & NA & 34 \\
\hline (Brusco, 2002) & Italian & 0 & NA & $8-21$ & NA \\
\hline (Jiang, $2005-2$ ) & Chinese & 0 & NA & NA & NA \\
\hline (Silveira, 2002) & $\begin{array}{c}\text { Portugal and } \\
\text { Brazil }\end{array}$ & 0 & NA & $8-28$ & NA \\
\hline (Tsai, 2004) & Taiwan & 0 & NA & $7-25$ & NA \\
\hline $\begin{array}{l}\text { (van de } \\
\text { Warrenburg, } \\
\text { 2002) }\end{array}$ & Netherlands & 0 & NA & NA & NA \\
\hline (Worth, 2001) & United Kingdom & 0 & NA & $7-30$ & NA \\
\hline (Cholfin, 2001) & United States & 0 & NA & $9-22$ & NA \\
\hline
\end{tabular}

Table 1. Summary of SCA12 descriptions available in the primary literature.

\section{Clinical features}

At present, SCA12 confirmed by genetic testing remains a very rare illness. However, as genetic testing, including whole genome sequencing, becomes common practice, the true incidence of SCA12 may prove to be much higher among previously categorized ADCA patients of unknown cause. Indeed, among a cohort of ADCA patients in India the incidence of SCA12 has proven to be much higher than in other geographical locales (Bahl et. al., 2005; Srivastava et. al., 2001). Given this observation, those who encounter ADCA patients should be aware of SCA12 and develop an index of suspicion informed by careful history taking, detailed neurological examination and deliberate laboratory testing.

As SCA12 has only been recognized as a distinct pathology for the last decade and, at present, only a very few patients have been described in the primary literature, an 
appreciation for the natural history of the disease is still evolving. By careful consideration of those cases that have been well characterized in the American, Indian, Italian and Chinese cohorts, a clinical picture of the SCA12 patient will be developed here. The descriptions provided here are intended to inform the clinician who encounters ADCA patients of unknown cause and to guide clinical decision-making.

\subsection{Patient reported history of illness}

Early in the course of the disease the prototypical SCA12 patient will present with postural and action tremor of the upper limbs. Age of onset of this tremor is highly variable with a range between 8 and 55 years, but seems to cluster primarily between the third and fifth decade of life (Brussino et. al., 2010; Fujigasaki et. al., 2001; Holmes et. al., 1999; O'Hearn et. al., 2001; Srivastava et. al., 2001). The first manifestations of the action tremor of the upper limbs have been described by patients as difficulty with activities requiring fine motor coordination, such as writing, as well as difficulties with activities requiring gross motor coordination such as attempting to hold and purposefully manipulate objects like a cup (Fujigasaki et. al., 2001; O'Hearn et. al., 2001). Observers describe the tremor as slowly progressive in nature with an increase in amplitude and involvement of the head and neck have been observed over the course of a decade (O'Hearn et. al., 2001). The action tremor of the upper limbs as the harbinger of the disease is unique to SCA12 and differentiates SCA12 from other ADCA disorders (Schols et. al., 2004; Teive, 2009). This tremor is not, however, universal among SCA12 patients, and its absence does not rule out SCA12 (Srivastava et. al., 2001; Wang, J et. al., 2011). Presentation of the upper limb action tremor is very similar to that of essential tremor and has previously been misdiagnosed as such early in the SCA12 course (O'Hearn et. al., 2001). Differentiating the SCA12 associated upper limb action tremor from isolated essential tremor requires an appreciation of the complete constellation of SCA12 associated symptoms as well as a family history consistent with ADCA.

\subsection{Neurological examination}

The time elapsed since disease onset has been reported to directly correlate with the number of neurological abnormalities (O'Hearn et. al., 2001). The examination of an SCA12 patient should therefore be informed by the patient reported history. To fully characterize the constellation of symptoms associated with SAC12 early in the course of the disease, care should be taken to elicit mild neurological abnormalities that may otherwise be subclinical in nature. Characterizing the gross neurological deficits present late in the course of the disease can serve to chart disease progression.

\subsubsection{Motor skills deficits}

As indicated above, the action tremor associated with SCA12 is one of the earliest hallmarks of the disease. Action tremor features include postural and kinetic properties, as well as a low frequency $(3 \mathrm{~Hz})\left(\mathrm{O}^{\prime}\right.$ Hearn et. al., 2001), and are similar to a tremor subset associated with cerebellar lesion termed "cerebellar postural tremor"(Hallett, 1991). As such, the postural features of the tremor can be elicited in the clinical setting by asking the patient to maintain their arms in an outstretched position and observing for limb tremor. The kinetic features of the tremor can be assessed by having the patient engage in a goal-directed movement of the upper limbs, such as finger-to-nose testing. Tremor should disappear 
completely while the upper limbs are at rest and not maintaining position against the force of gravity.

Loss of motor coordination due to cerebellar dysfunction associated with SCA12 manifests when the patient engages in a number of activities. During finger-to-nose testing, rather than smooth, rapid, accurate movements, the SCA12 patient will display slow, hesitant, inaccurate movements consistent with upper limb dysmetria. Further, the SCA12 patient has been reported to be unable to engage in rapid alternating movements (dysdiadochokinesia) such as alternating between turning the palms or the back of the hand face up (O'Hearn et. al., 2001). Motor deficits also disrupt speech and can result in dysarthria (O'Hearn et. al., 2001; Srivastava et. al., 2001).

Parkinsonain features have also been described in SCA12 patients from the American Cohort. These manifest as paucity of spontaneous movements, mild bradykinesia, upper limb rigidity and postural anteroflexion (O'Hearn et. al., 2001).

A great deal of heterogeneity has been observed in the symptoms of SCA12 patients from different ethnic backgrounds. Unique to the Indian cohort, facial myokymia has also been described in a small number of SCA12 patients (Srivastava et. al., 2001). Although the proband of the Chinese cohort developed generalized ataxia during the third decade of life, action tremor has not been observed (Wang, J et. al., 2011).

\subsubsection{Gait abnormalities}

The ataxic gait of the SCA12 patient has been described as being very similar to that observed in other diseases with cerebellar dysfunction. The SCA12 patient maintains stability by adopting a broad based stance. Parkinsonian features have also manifest in the gait among individuals of the American Cohort (O'Hearn et. al., 2001). Initiation of movement is delayed. Steps have been described as hesitant, small and slow. When turning, the SCA12 patient has been described as engaging in an "en bloc" approach. A mild ataxic phenotype can be exaggerated by having the patient maintain a tandem gait, wherein the patient walks in a straight line with the heel of the front foot touching the toes of the back foot at each step.

\subsubsection{Cranial nerve assessment}

With the exception of oculomotor nerve (CNIII) abnormalities, the cranial nerves are largely intact and function without deficit in the SCA12 patient. Horizontal nystagmus has been described and may represent an early manifestation of the disease (Fujigasaki et. al., 2001; Holmes et. al., 2003; O'Hearn et. al., 2001; Srivastava et. al., 2001). In addition slow saccades and broken pursuit have been described in SCA12 patients from the Indian cohort (Fujigasaki et. al., 2001; Srivastava et. al., 2001).

\subsubsection{Assessment of reflexes}

Diffuse hyperreflexia has been described for SCA12 patients from the American, Indian and Italian cohorts (Brussino et. al., 2010; Fujigasaki et. al., 2001; O'Hearn et. al., 2001; Srivastava et. al., 2001). A return of primitive reflexes in the otherwise mature SCA12 patient has also been described. These reflexes include an extensor plantar response (positive Babinski sign), grasp reflex, rooting reflex and glabellar blink reflex (Myerson sign). 


\subsubsection{Mental Status}

Psychiatric disorders have been reported to occur concurrently with SCA12. Anxiety and depression have been reported in members of the American cohort, but not the Indian or Italian cohorts (Brussino et. al., 2010; O'Hearn et. al., 2001; Srivastava et. al., 2001). Whether these disorders result as a direct consequence of the SCA12 disease process or represent an individual response to the presence of the disease is unclear. Paranoid delusions have also been reported in one SCA12 patient (O'Hearn et. al., 2001). A decline in cognition has been described in SCA12 patients two to three decades after initial onset of the disease (Fujigasaki et. al., 2001; O'Hearn et. al., 2001).
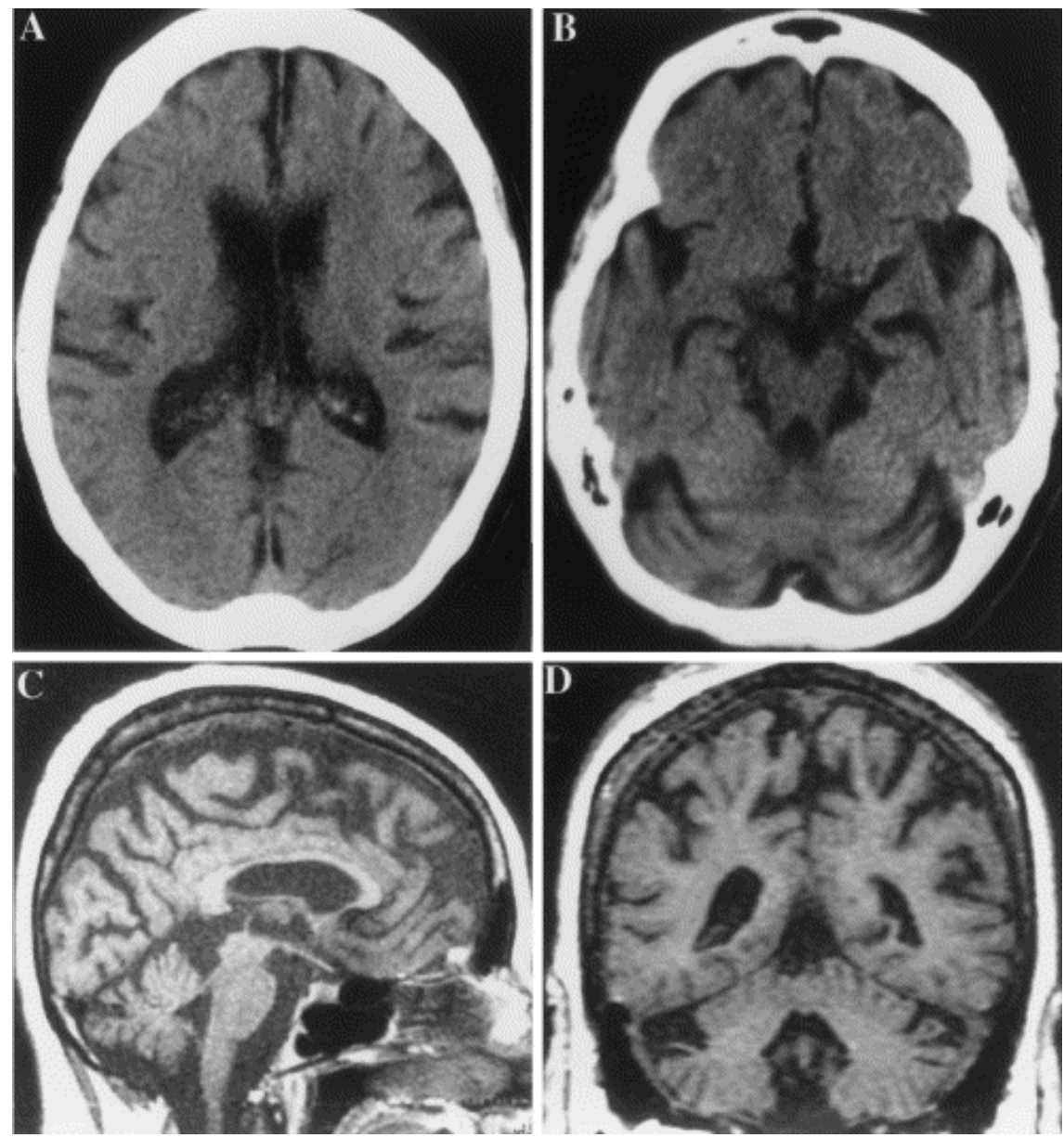

Fig. 1. Neuroradiologic images from two patients with spinocerebellar ataxia type 12. (A,B) Coronal computed tomography of the proband at age 62 years reveals cerebellar and diffuse cerebral cortical atrophy. (C) (sagittal), (D) (coronal): T-1 weighted magnetic resonance images of a 59-year-old affected woman also shows cerebellar and cortical atrophy. Reproduced from Holmes et. al. (2001), with permission from Elsevier Science. 


\subsection{Neuroimaging studies}

Computerized tomography (CT) and magnetic resonance imaging (MRI) studies of symptomatic SCA12 patients reveal that mild to moderate cerebellar and cortical atrophy is a near universal finding of the disease (Brussino et. al., 2010; Fujigasaki et. al., 2001; O'Hearn et. al., 2001; Srivastava et. al., 2001; Wang, J et. al., 2011). An example of these findings from imaging studies performed on members of the American cohort of SCA12 patients is shown (Figure 1). The cerebellar vermis appears to be more vulnerable to atropy than the cerebellar hemispheres (O'Hearn et. al., 2001). Atrophy of subcortical structures has not been described. Additional characterization by single-proton emission computed tomography (SPECT) revealed metabolic deficiencies in atrophic cortical areas; however, the value of this test is uncertain in the symptomatic patient (Fujigasaki et. al., 2001). Proton magnetic resonance spectroscopy has been used to demonstrate neurometabolic and microstructural changes in the SCA12 patient (Brussino et. al., 2010), and this technique represents a noninvasive method that may longitudinally describe the asymptomatic SCA12 patient.

\subsection{Genetic testing}

Genetic testing for the presence of CAG repeat expansion is available. The reader is directed to the GeneTests Laboratory Directory available online (http://www.ncbi.nlm. nih.gov/sites/GeneTests/lab) for a list of available testing centers. The small sample size of affected individuals currently identified has left the question of penetrance of the disease open. Therefore, a great deal of care should be exercised when interpreting the results of a genetic test from an asymptomatic patient.

\subsection{Medical management}

Currently, management of SCA12 is limited to providing symptomatic relief for the action tremor. Treatment of the SCA12 action tremor is very similar to that provided for essential tremor. A reduction in tremor amplitude has been achieved with beta-blockers and barbiturates (O'Hearn et. al., 2001). When appropriate, pharmacological relief for symptoms associated with the disease such as depression and anxiety should be offered to the SCA12 patient.

\section{PPP2R2B gene regulation and protein function}

\subsection{PP2A and B regulatory subunit}

Protein phosphorylation is the most common posttranslational modification of proteins, and it plays a role in nearly every cellular function. The addition of phosphate is mediated through a large group $(>500)$ of enzymes called kinases and requires ATP as a substrate. The reverse reaction is mediated by a smaller number of protein phosphatases in which, in most cases, specificity is provided through the formation of multimeric protein complexes. One of the most abundant protein phosphatase is PP2A, which is an essential, ubiquitously expressed phosphatase that targets phospho-serine and phospho-threonine. PP2A exists as a heterotrimer composed of one member of four diverse families of regulatory subunits (B), a scaffolding subunit (A) and a catalytic subunit (C) (Figure 2). Humans express 4 families of 
regulatory subunits termed $\mathrm{B}, \mathrm{B}^{\prime}, \mathrm{B}^{\prime \prime}$, and $\mathrm{B}^{\prime \prime \prime}$, which determine both cellular localization and substrate specificity (Slupe et. al., 2011). The B family, also known B55, consists of 4 distinct genes $(\alpha, \beta, \gamma, \delta)$ that encode proteins containing a highly conserved core WD40 domain, which has propeller like structure, with over $90 \%$ amino acid identity among the family members (Figure $2 \mathrm{~B}$ ). The $\mathrm{B} \beta$ regulatory subunit is encoded by the PPP2R2B gene, which has several splice-variants that are expressed exclusively in neuronal tissue.
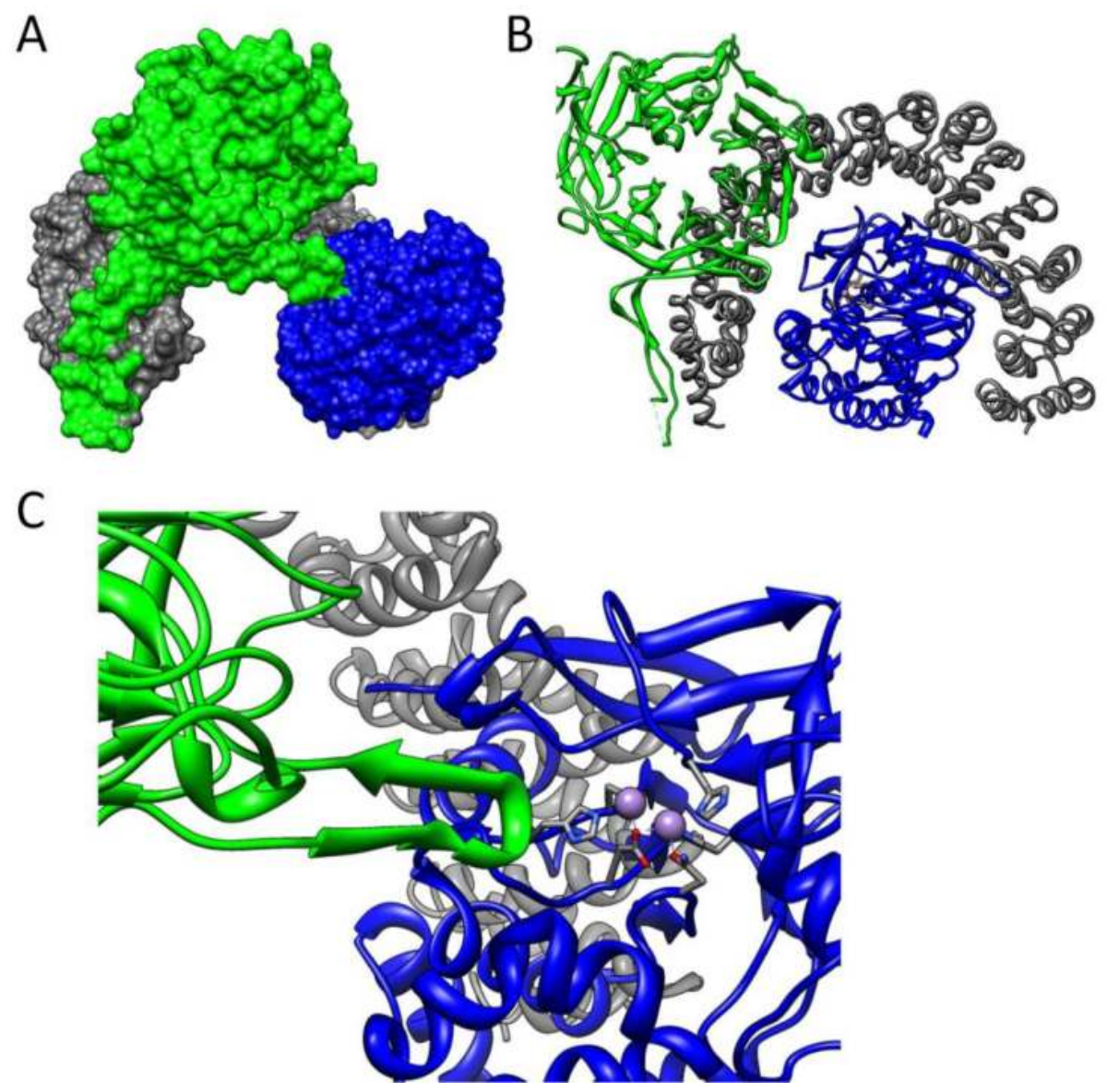

Fig. 2. Models of PP2A/Ba prepared from PDB 3DW8. The subunits of the heterotrimeric complex are color coded with the catalytic subunit (C) in blue, the scaffold subunit (A) in gray, and the regulatory subunit (B) in green. A, "top-down" view of the heterotrimer suface. B, "end-on" view of the heterotrimer ribbon diagram. C, Close of view of the PP2A active site highlighting infiltration of a regulatory subunit loop into the catalytic cleft. 


\subsection{Gene structure and expression}

The exon arrangement of the PPP2R2B gene is highly conserved among mammals and spread over more than 500,000 base pairs (Dagda et. al., 2003; Schmidt et. al., 2002). Exon 1.1 and 1.2 are alternatively expressed first exons containing the ATG start site for the splice variants $\mathrm{B} \beta 1$ and $\mathrm{B} \beta 2$, respectively. These first exons, which contain the unique aminotermini, are spliced to common exons 2-9 that encode the WD40 domain found in all the B family of regulatory subunits (Figure 3) (Dagda et. al., 2003). At the mRNA level, B $\beta 1$ and $\mathrm{B} \beta 2$ are expressed prominently in brain tissue, and $\mathrm{B} \beta 1$ can also be found in the testis (Dagda et. al., 2003). At the protein level, western blot analysis indicates that the B $\beta 1$ is exclusively expressed in brain tissue and not in the testis, despite the high mRNA expression in that tissue. Closer analysis of specific brain regions has shown high levels of the $B \beta 1$ protein throughout the brain (Strack et. al., 1998).

\subsubsection{Transcriptional regulation}

The CAG trinucleotide repeat expansion associated with the SCA12 disease is situated just upstream of the transcriptional start site of the B $\beta 1$ specific exon 1.1. A recent study identified the apparent transcriptional regulators for basal expression of the $B \beta 1$ promoter and the effect of the CAG repeat on basal expression (Lin et. al., 2010). Luciferase assays using deletions of the $\mathrm{B} \beta 1$ promoter and chromatin immunoprecipitation assays reveal that

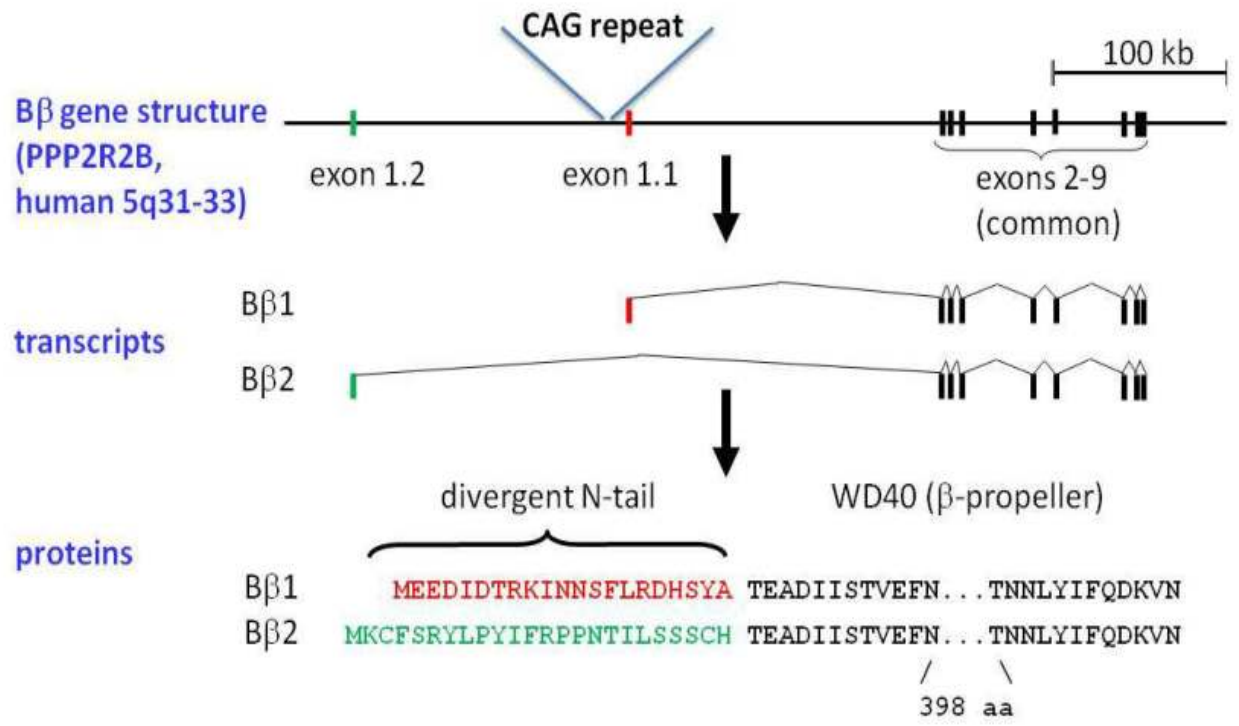

Fig. 3. Schematic representation of PPP2R2B gene structure, splice variant transcripts and proteins. The gene structure shows the CAG repeat expansion location, the B $\beta 1$ (exon 1.1; red) and $B \beta 2$ N-terminal coding sequences (exon 1.2; green). Transcripts and proteins indicate the $\mathrm{B} \beta 1$ (red) and $\mathrm{B} \beta 2$ (green) splice variant specific transcripts and encoded proteins. Modified from Dagda et. al. (2003). 
CREB1, SP1 and TRAP4 bind to and regulate the B $\beta 1$ promoter. Higher luciferase activity is seen in neuronal cell lines and correlates well with the known B $\beta 1$ neuronal expression. Interestingly, increasing the size of the CAG repeat in the $B \beta 1$ promoter increased the promoter activity two-fold. The increased activity is specific to the expansion of the CAG and not a result of changing the spacing of promoter since no change is seen in an AT expansion control (Lin et. al., 2010). A normal length CAG repeat does appear to be important for basal promoter activity since decreasing the number of CAG repeats reduced the promoter activity (Chen et. al., 2009). Independent studies conducted in Japan and Taiwan found that patients suffering from Alzheimer's disease had an increased likelihood of having a reduced number of CAG trinucleotide repeats compared to healthy control subjects (Chen et. al., 2009; Kimura et. al., 2011). Overall, these studies have identified important aspects of the PPP2R2B transcriptional regulation and help to discriminate between the role of the CAG repeat in providing basal transcriptional activation and the pathological effects of increasing or decreasing the trinucleotide repeat number.

A recently identified Japanese autosomal dominant cerebellar ataxia raises more uncertainty about the role of PPP2R2B gene in SCA12. The disease locus for this new ataxia included the PPP2R2B gene but contained no CAG expansion (Sato et. al., 2010). Additionally, all exons and intron/exon borders were sequenced for the entire PPP2R2B gene, including the both first exons (1.1 and 1.2), and no mutations were discovered. Several neuronally expressed genes are within the identified locus and may contain the genetic insult resulting in the ataxia (Sato et al 2010). This does raise the possibility that some of the effects of the CAG expansion in the PPP2R2B gene may be mediated through dysregulation of other nearby genes and not just changes in $\mathrm{B} \beta$ gene expression.

\subsubsection{PPP2R2B regulation and cancer}

Another important form of regulation of $\mathrm{B} \beta 1$ occurs in colorectal cancer (CRC) wherein developed cell lines show a decrease or complete absence of B $\beta 1$ expression (Tan et. al., 2010). Furthermore, gene array comparisons of matched patient-derived mucosa controls and CRC tumors indicate a significant decrease in $B \beta 1$ expression in $90 \%$ of the tumors. The loss of $\mathrm{B} \beta 1$ expression is mediated through hypermethylation of a $\mathrm{CpG}$ island that occurs in the $\mathrm{B} \beta 1$ promoter. Aberrant methylation of the PPP2R2B gene also appears to be important in breast cancer, as seen in recent reports (Dejeux et. al., 2010; Muggerud et. al., 2010). Finally, an intronic SNP of the PPP2R2B gene, with unknown functional consequence, is correlated with improved prognosis in a breast cancer cohort (Vazquez et. al., 2011). These studies clearly indicate that regulation of the PPP2R2B gene is important in multiple cancers and may provide additional insight into the function of the PPP2R2B gene.

\subsection{Protein function}

The $B \beta 1$ and $B \beta 2$ splice variants encode proteins that share a common WD40 repeat domain that mediates the recruitment of the $\mathrm{A}$ and $\mathrm{C}$ subunits of PP2A to make a functional trimeric protein phosphatase. The $\mathrm{B} \beta 1$ and $\mathrm{B} \beta 2$ proteins differ only in the first 21 and 24 amino acids, respectively, but this leads to a dramatic difference in the protein distribution within the cell. 


\subsection{1 $\mathrm{B} \beta 1$ protein function}

B $\beta 1$ has a cytoplasmic distribution and overexpression in cultured primary neurons does not change the morphology, survival or sensitivity to toxic treatments (Figure 4) (Dagda et. al., 2008). Overexpression of $B \beta 1$ in a neuroblastoma cell line does result in increased autophagy (Cheng et. al., 2009). In CRC the loss of B $\beta 1$ following methylation of the CpG island leads to aberrant phosphorylation of several proteins, including the oncogene c-myc. Reexpression of B $\beta 1$ in a colorectal cell line decreases xenograft growth (Tan et. al., 2010). This represents the first described pathway regulated specifically by a B $\beta 1$ containing PP2A trimer. Since some of the proteins regulated by $B \beta 1$ in CRC are also expressed in neuronal tissues, it may be of interest to examine whether the B $\beta 1$-mediated changes in phosphorylation also play a role in SCA12.

\subsection{2 $\mathrm{B} \beta 2$ protein function}

The $\mathrm{B} \beta 2 \mathrm{~N}$-terminus encodes a mitochondrial targeting sequence that results in recruitment of the trimeric PP2A enzyme to the outer mitochondrial membrane (OMM) (Dagda et. al., 2003). In primary hippocampal neurons, PP2A-mediated phosphatase activity at the OMM, through recruitment by $\mathrm{B} \beta 2$, results in mitochondrial fragmentation and increased basal death and sensitivity to neurotoxic insults (Figure 4) (Dagda et. al., 2005; Dagda et. al., 2008). Expression of $\mathrm{B} \beta 2$ mutants, that either do not target to the OMM or cannot recruit the A and $\mathrm{C}$ subunits, prevents the mitochondrial fragmentation and increased neuronal death (Figure 4) (Dagda et. al., 2008). Epitasis experiments indicate that the PP2A/B $\beta 2$-mediated mitochondrial fragmentation precedes and is obligatory to the increased neuronal cell death (Dagda et. al., 2008). An additional study, utilizing neuroblastoma cells, confirmed the increased sensitivity of cells expressing $B \beta 2$ but implicated an increase in autophagy as the culprit in the increased cell death (Cheng et. al., 2009).

Mitochondrial dysfunction is a hallmark of several neurodegenerative diseases, including Alzheimer disease. It can therefore be postulated that the CAG trinucleotide repeat expansion, which is known to increase $B \beta 1$ promoter activity, amplifies both $B \beta 1$ and $B \beta 2$ expression. The $B \beta 2$ upregulation may lead to increased mitochondrial fragmentation and increasing mitochondrial dysfunction in SCA12. Indeed, several other ataxias involve mitochondrial dysfunction. In patients suffering from SCA7, both liver and skeletal muscle biopsies show abnormal mitochondria (Han et. al., 2010). Heterozygous knockout mice for AFG3L2, a mitochondrial-targeted AAA-protease, develop abnormal mitochondria with decreased function and are a model of SCA28 (Maltecca et. al., 2009). Finally, in clinical trials pharmacological treatments with idebenone, an antioxidant thought to counteract mitochondrial dysfunction, have shown some promise in treatment of the genetic neurological disorder Friedreich ataxia (Marmolino, 2011). These examples highlight some of the ataxias associated with mitochondrial dysfunction and exemplify why mitochondrial dysfunction could be an important aspect of SCA12.

\subsection{Animal models of SCA12}

While characterization of the PPP2R2B gene products has suggested possible pathogenic mechanisms, animal models of SCA12 are urgently needed to test the predictions of the in 


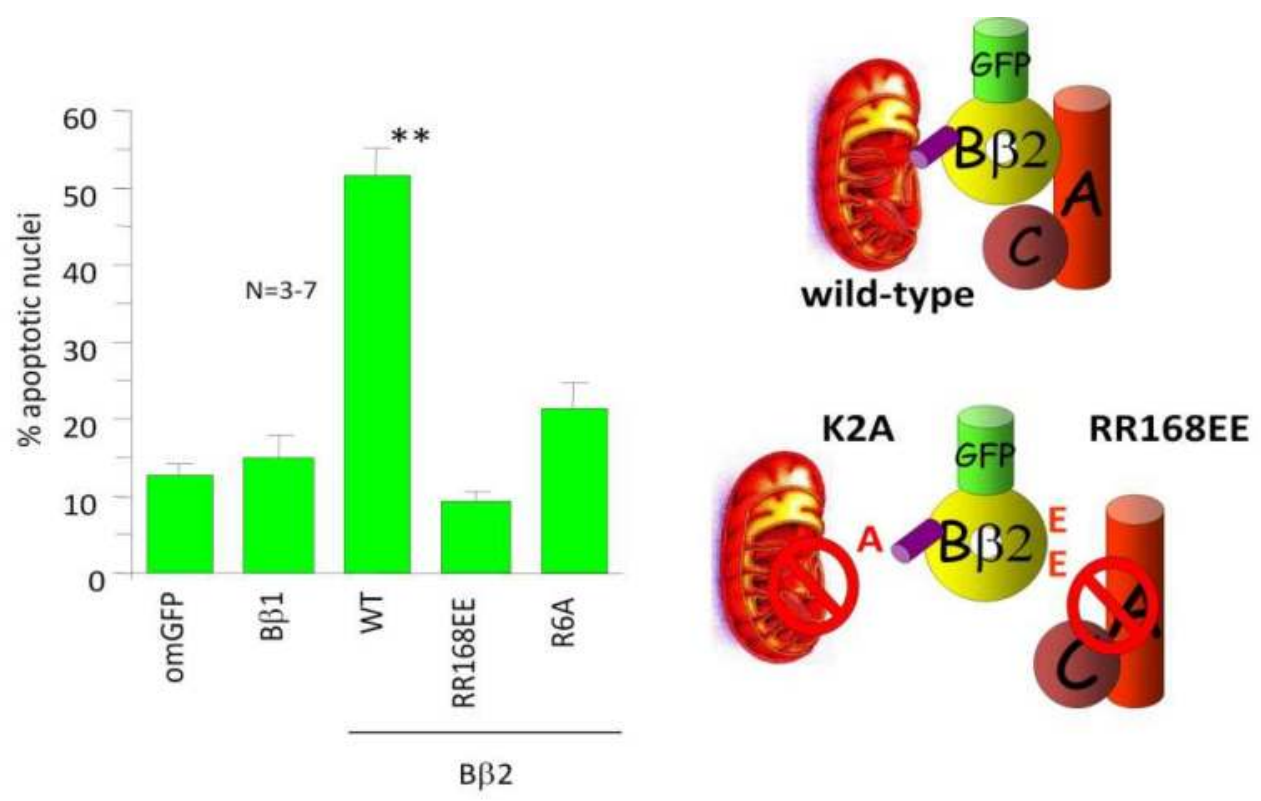

Fig. 4. Mitochondrial targeting of PP2A/B $\beta 2$ is neurotoxic. Hippocampal neurons were transfected with the indicated GFP fusion proteins (om, outer mitochondrial; WT, wildtype) and scored for apoptotic nuclei. $\mathrm{B} \beta 2$ mutants that block mitochondrial localization (R6A) or AC dimer recruitment (RR168EE) also block apoptosis induction. Modified from Dagda et. al. (2008).

vitro studies discussed above. A recently developed fly model of SCA12 does display some neuropathies that may be homologous to the human disease (Wang, YC et. al., 2011). In this model, Drosophila overexpresses the human B $\beta 2$ or tws, the fly homolog of $B \beta$, which results in a dramatic increase in neuronal apoptosis and, for the highest level of tws, a decrease in fly life span. Overexpression of tws results in mitochondrial fragmentation and dysfunction, observed as an increase in reactive oxygen species (ROS) production. Expression of superoxide dismutase 2 or antioxidants treatments reduces ROS production and attenuates the effects of tws overexpression. How the neuropathies and their reversal by pharmacological treatments seen in the fly SCA12 model relate to the human disease remains to be seen. 


\section{Conclusion}

The CAG trinucleotide repeat expansion that occurs in the PPP2R2B gene is now well established as the cause of the autosomal dominant SCA12. This is a rare disease that shows a classical ataxia phenotype. The CAG repeat occurs in the promoter of a neuronally expressed protein, $B \beta 1$, and expansion of the CAG results in increased $B \beta 1$ promoter activity. Aberrant expression of $\mathrm{B} \beta 1$ also correlates with several cancers. Expression of another neuronal splice variant of PPP2R2B, B $\beta 2$, increases neuronal death, but its role in SCA12 remains unknown. Despite the identified PPP2R2B gene functions, the underlying molecular basis of the SCA12 disease is not known. Animal models are needed to address the complexity of SCA12 and develop potential therapeutic treatments. The fly model of SCA12 does show mitochondrial dysfunction and recapitulates some neuron specific cell death (Wang, YC et. al., 2011); however, the development of a mammalian model system will likely be required to understand the molecular basis of SCA12 pathogenesis.

\section{Acknowledgment}

The authors would like to thank Drs. Nicole Worden and Melissa Bose for critically evaluating this manuscript.

\section{References}

Bahl S, Virdi K, Mittal U, Sachdeva MP, Kalla AK, Holmes SE, O'Hearn E, Margolis RL, Jain S, Srivastava AK\& Mukerji M. (2005). Evidence of a common founder for SCA12 in the Indian population. Annals of Human Genetics. Vol. 69, No. Pt 5, (September 2005),pp.528-534, ISSN 0003-4800

Brusco A, Cagnoli C, Franco A, Dragone E, Nardacchione A, Grosso E, Mortara P, Mutani R, Migone N\& Orsi L. (2002). Analysis of SCA8 and SCA12 loci in 134 Italian ataxic patients negative for SCA1-3, 6 and 7 CAG expansions. Journal of Neurology. Vol. 249, No. 7, (Jul 2002), pp.923-929, ISSN 0340-5354

Brussino A, Graziano C, Giobbe D, Ferrone M, Dragone E, Arduino C, Lodi R, Tonon C, Gabellini A, Rinaldi R, Miccoli S, Grosso E, Bellati MC, Orsi L, Migone N\& Brusco A. (2010). Spinocerebellar ataxia type 12 identified in two Italian families may mimic sporadic ataxia. Movement Disorders. Vol. 25, No. 9, (July 2010),pp.1269-1273, ISSN 1531-8257

Chen CM, Hou YT, Liu JY, Wu YR, Lin CH, Fung HC, Hsu WC, Hsu Y, Lee SH, Hsieh-Li HM, Su MT, Chen ST, Lane HY\& Lee-Chen GJ. (2009). PPP2R2B CAG repeat length in the Han Chinese in Taiwan: Association analyses in neurological and psychiatric disorders and potential functional implications. American Journal of Medical Genetics Part B, Neuropsychiatric genetics. Vol. 150B, No. 1, (January 2009),pp.124-129, ISSN 1552-485X

Cheng WT, Guo ZX, Lin CA, Lin MY, Tung LC\& Fang K. (2009). Oxidative stress promotes autophagic cell death in human neuroblastoma cells with ectopic 
transfer of mitochondrial PPP2R2B (Bbeta2). BMC Cell Biology. Vol. 10, pp.91, ISSN 1471-2121

Cholfin JA, Sobrido MJ, Perlman S, Pulst SM\& Geschwind DH. (2001). The SCA12 mutation as a rare cause of spinocerebellar ataxia. Archives of Neurology. Vol. 58, No. 11, (Nov 2001), pp.1833-1835, ISSN 0003-9942

Dagda RK, Zaucha JA, Wadzinski BE\& Strack S. (2003). A developmentally regulated, neuron-specific splice variant of the variable subunit Bbeta targets protein phosphatase 2A to mitochondria and modulates apoptosis. Journal of Biological Chemistry. Vol. 278, No. 27, (July 2003), pp.24976-24985, ISSN 0021-9258

Dagda RK, Barwacz CA, Cribbs JT\& Strack S. (2005). Unfolding-resistant translocase targeting: a novel mechanism for outer mitochondrial membrane localization exemplified by the Bbeta2 regulatory subunit of protein phosphatase 2A. Journal of Biological Chemistry. Vol. 280, No. 29, (July 2005), pp.27375-27382, ISSN 00219258

Dagda RK, Merrill RA, Cribbs JT, Chen Y, Hell JW, Usachev YM\& Strack S. (2008). The spinocerebellar ataxia 12 gene product and protein phosphatase $2 \mathrm{~A}$ regulatory subunit Bbeta2 antagonizes neuronal survival by promoting mitochondrial fission. Journal of Biological Chemistry. Vol. 283, No. 52, (December 2008), pp.36241-36248, ISSN 0021-9258

Dejeux E, Ronneberg JA, Solvang H, Bukholm I, Geisler S, Aas T, Gut IG, Borresen-Dale AL, Lonning PE, Kristensen VN\& Tost J. (2010). DNA methylation profiling in doxorubicin treated primary locally advanced breast tumours identifies novel genes associated with survival and treatment response. Molecular Cancer. Vol. 9, (March 2010), pp.68, ISSN 1476-4598

Fujigasaki H, Verma IC, Camuzat A, Margolis RL, Zander C, Lebre AS, Jamot L, Saxena R, Anand I, Holmes SE, Ross CA, Durr A\& Brice A. (2001). SCA12 is a rare locus for autosomal dominant cerebellar ataxia: a study of an Indian family. Annals of Neurology. Vol. 49, No. 1, (January 2001), pp.117-121, ISSN 0364-5134

Hallett M. (1991). Classification and treatment of tremor. Journal of the American Medical Association. Vol. 266, No. 8, (August 1991), pp.1115-1117, ISSN 0098-7484

Han Y, Deng B, Liu M, Jiang J, Wu S\& Guan Y. (2010). Clinical and genetic study of a Chinese family with spinocerebellar ataxia type 7. Neurology India. Vol. 58, No. 4, (July-August 2010), pp.622-626, ISSN 0028-3886

Holmes SE, O'Hearn E\& Margolis RL. (2003). Why is SCA12 different from other SCAs? Cytogenetic and Genome Research. Vol. 100, No. 1-4, pp.189-197, ISSN 1424$859 \mathrm{X}$

Holmes SE, O'Hearn EE, McInnis MG, Gorelick-Feldman DA, Kleiderlein JJ, Callahan C, Kwak NG, Ingersoll-Ashworth RG, Sherr M, Sumner AJ, Sharp AH, Ananth U, Seltzer WK, Boss MA, Vieria-Saecker AM, Epplen JT, Riess O, Ross CA\& Margolis RL. (1999). Expansion of a novel CAG trinucleotide repeat in the 5 region of PPP2R2B is associated with SCA12. Nature Genetics. Vol. 23, No. 4, (December

Janssens V\& Goris J. (2001). Protein phosphatase 2A: a highly regulated family of serine/threonine phosphatases implicated in cell growth and signalling. 
Biochemical Journal. Vol. 353, No. Pt 3, (February 2001), pp.417-439, ISSN 02646021

Jiang H, Tang B, Xia K, Zhou Y, Xu B, Zhao G, Li H, Shen L, Pan Q\& Cai F. (2005-1). Spinocerebellar ataxia type 6 in Mainland China: molecular and clinical features in four families. Journal of the Neurological Sciences. Vol. 236, No. 1-2, (September 2005), pp.25-29, ISSN 0022-510X

Jiang H, Tang BS, Xu B, Zhao GH, Shen L, Tang JG, Li QH\& Xia K. (2005-2). Frequency analysis of autosomal dominant spinocerebellar ataxias in mainland Chinese patients and clinical and molecular characterization of spinocerebellar ataxia type 6. Chinese Medical Journal. Vol. 118, No. 10, (May 2005), pp.837-843, ISSN 03666999

Kimura R, Morihara T, Kudo T, Kamino K\& Takeda M. (2011). Association between CAG repeat length in the PPP2R2B gene and Alzheimer disease in the Japanese population. Neuroscience Letters. Vol. 487, No. 3, (January 2011), pp.354-357, ISSN 1872-7972

Lin CH, Chen CM, Hou YT, Wu YR, Hsieh-Li HM, Su MT\& Lee-Chen GJ. (2010). The CAG repeat in SCA12 functions as a cis element to up-regulate PPP2R2B expression. Human Genetics. Vol. 128, No. 2, (August 2010), pp.205-212, ISSN 1432-1203

Maltecca F, Magnoni R, Cerri F, Cox GA, Quattrini A\& Casari G. (2009). Haploinsufficiency of AFG3L2, the gene responsible for spinocerebellar ataxia type 28, causes mitochondria-mediated Purkinje cell dark degeneration. The Journal of Neuroscience. Vol. 29, No. 29, (July 2009), pp.9244-9254, ISSN 15292401

Marmolino D. (2011). Friedreich's ataxia: past, present and future. Brain Research Reviews. Vol. 67, No. 1-2, (June 2011), pp.311-330, ISSN 1872-6321

Muggerud AA, Ronneberg JA, Warnberg F, Botling J, Busato F, Jovanovic J, Solvang H, Bukholm I, Borresen-Dale AL, Kristensen VN, Sorlie T\& Tost J. (2010). Frequent aberrant DNA methylation of ABCB1, FOXC1, PPP2R2B and PTEN in ductal carcinoma in situ and early invasive breast cancer. Breast Cancer Research. Vol. 12, No. 1, (January 2010), pp.R3, ISSN 1465-542X

O'Hearn E, Holmes SE, Calvert PC, Ross CA\& Margolis RL. (2001). SCA-12: Tremor with cerebellar and cortical atrophy is associated with a CAG repeat expansion. Neurology. Vol. 56, No. 3, (February 2001),pp.299-303

Sato K, Yabe I, Fukuda Y, Soma H, Nakahara Y, Tsuji S\& Sasaki H. (2010). Mapping of autosomal dominant cerebellar ataxia without the pathogenic PPP2R2B mutation to the locus for spinocerebellar ataxia 12. Archives of Neurology. Vol. 67, No. 10, (October 2010), pp.1257-1262, ISSN 1538-3687

Schmidt K, Kins S, Schild A, Nitsch RM, Hemmings BA\& Gotz J. (2002). Diversity, developmental regulation and distribution of murine PR55/B subunits of protein phosphatase 2A. The European Journal of Neuroscience. Vol. 16, No. 11, (December 2002), pp.2039-2048, ISSN 0953-816X

Schols L, Bauer P, Schmidt T, Schulte T\& Riess O. (2004). Autosomal dominant cerebellar ataxias: clinical features, genetics, and pathogenesis. Lancet Neurology. Vol. 3, No. 5, (May 2004), pp.291-304, ISSN 1474-4422 
Silveira I, Miranda C, Guimaraes L, Moreira MC, Alonso I, Mendonca P, Ferro A, PintoBasto J, Coelho J, Ferreirinha F, Poirier J, Parreira E, Vale J, Januario C, Barbot C, Tuna A, Barros J, Koide R, Tsuji S, Holmes SE, Margolis RL, Jardim L, Pandolfo M, Coutinho P\& Sequeiros J. (2002). Trinucleotide repeats in 202 families with ataxia: a small expanded (CAG)n allele at the SCA17 locus. Archives of Neurology. Vol. 59, No. 4, (Apr 2002), pp.623-629, ISSN 0003-9942

Slupe AM, Merrill RA\& Strack S. (2011). Determinants for Substrate Specificity of Protein Phosphatase 2A. Enzyme Research. Vol. 2011, pp.398751, ISSN 2090-0414

Srivastava AK, Choudhry S, Gopinath MS, Roy S, Tripathi M, Brahmachari SK\& Jain S. (2001). Molecular and clinical correlation in five Indian families with spinocerebellar ataxia 12. Annals of Neurology. Vol. 50, No. 6, (December 2001), pp.796-800, ISSN 0364-5134

Strack S, Zaucha JA, Ebner FF, Colbran RJ\& Wadzinski BE. (1998). Brain protein phosphatase 2A: developmental regulation and distinct cellular and subcellular localization by B subunits. The Journal of Comparative Neurology. Vol. 392, No. 4, (March 1998), pp.515-527, ISSN 0021-9967

Tan J, Lee PL, Li Z, Jiang X, Lim YC, Hooi SC \& Yu Q. (2010) B55 $\square$-Associated PP2A Complex Controls PDK1-Directed Myc Signaling and Modulates Rapamycin Sensitivity in Colorectal Cancer. Cancer Cell. Vol. 18, (November 2010), pp.459471, ISSN 0028-0836

Teive HA. (2009). Spinocerebellar ataxias. Arquivos de Neuropsiquiatria. Vol. 67, No. 4, (December 2009), pp.1133-1142, ISSN 1678-4227

Tsai HF, Liu CS, Leu TM, Wen FC, Lin SJ, Liu CC, Yang DK, Li C\& Hsieh M. (2004). Analysis of trinucleotide repeats in different SCA loci in spinocerebellar ataxia patients and in normal population of Taiwan. Acta Neurologica Scandinavica. Vol. 109, No. 5, 2004), pp.355-360, ISSN 1600-0404.

Vazquez A, Kulkarni D, Grochola LF, Bond GL, Barnard N, Toppmeyer D, Levine AJ\& Hirshfield KM. (2011). A genetic variant in a PP2A regulatory subunit encoded by the PPP2R2B gene associates with altered breast cancer risk and recurrence. International Journal of Cancer. Vol. 128, No. 10, (May 2011), pp.2335-2343, ISSN 1097-0215

van de Warrenburg BPC, Sinke RJ, Verschuuren,ÄìBemelmans CC, Scheffer H, Brunt ER, Ippel PF, Maat-Kievit JA, Dooijes D, Notermans NC, Lindhout D, Knoers NVAM\& Kremer HPH. (2002). Spinocerebellar ataxias in the Netherlands. Neurology. Vol. 58, No. 5, (March 12, 2002), pp.702-708

Wang J, Shen L, Lei L, Xu Q, Zhou J, Liu Y, Guan W, Pan Q, Xia K, Tang B\& Jiang H. (2011). Spinocerebellar ataxias in mainland China: an updated genetic analysis among a large cohort of familial and sporadic cases. Zhong Nan Da Xue Xue Bao Yi Xue Ban. Vol. 36, No. 6, (June 2011), pp.482-489, ISSN 1672-7347

Wang YC, Lee CM, Lee LC, Tung LC, Hsieh-Li HM, Lee-Chen GJ\& Su MT. (2011). Mitochondrial Dysfunction and Oxidative Stress Contribute to the Pathogenesis of Spinocerebellar Ataxia Type 12 (SCA12). Journal of Biological Chemistry. Vol. 286, No. 24, (June 2011), pp.21742-21754, ISSN 1083-351X 
Worth PF \& Wood NW. (2001). Spinocerebellar ataxia type 12 is rare in the United Kingdom. Neurology. Vol. 56, No. 3, (Feb 13 2001),pp.419-420, ISSN 00283878 


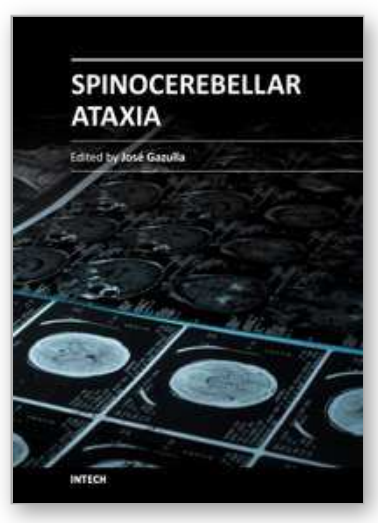

\author{
Spinocerebellar Ataxia \\ Edited by Dr. José Gazulla
}

ISBN 978-953-51-0542-8

Hard cover, 198 pages

Publisher InTech

Published online 18, April, 2012

Published in print edition April, 2012

The purpose of this book has been to depict as many biochemical, genetic and molecular advances as possible, in the vast field of the spinocerebellar ataxias.

\title{
How to reference
}

In order to correctly reference this scholarly work, feel free to copy and paste the following:

Ronald A. Merrill, Andrew M. Slupe and Stefan Strack (2012). Spinocerebellar Ataxia Type 12 (SCA 12):

Clinical Features and Pathogenetic Mechanisms, Spinocerebellar Ataxia, Dr. José Gazulla (Ed.), ISBN: 978953-51-0542-8, InTech, Available from: http://www.intechopen.com/books/spinocerebellarataxia/spinocerebellar-ataxia-type-12-sca-12-clinical-features-and-pathogenetic-mechanisms

\section{INTECH}

open science | open minds

\section{InTech Europe}

University Campus STeP Ri

Slavka Krautzeka 83/A

51000 Rijeka, Croatia

Phone: +385 (51) 770447

Fax: +385 (51) 686166

www.intechopen.com

\section{InTech China}

Unit 405, Office Block, Hotel Equatorial Shanghai

No.65, Yan An Road (West), Shanghai, 200040, China 中国上海市延安西路65号上海国际贵都大饭店办公楼 405 单元

Phone: +86-21-62489820

Fax: $+86-21-62489821$ 
(C) 2012 The Author(s). Licensee IntechOpen. This is an open access article distributed under the terms of the Creative Commons Attribution 3.0 License, which permits unrestricted use, distribution, and reproduction in any medium, provided the original work is properly cited. 